\title{
NO CHANCE OF SUCCESS. STATE AGRARIAN REAL ESTATE 1946-1949. A CONTRIBUTION TO THE RESEARCH ON THE HISTORY OF THE STATE AGRICULTURAL SECTOR IN POLAND
}

\begin{abstract}
The years of activity of the PNZ (Państwowe Nieruchomości Ziemskie - State Agrarian Real Estate) fell into the period of post-war agricultural reconstruction and management of Recovered Territories. Initially, their main task was to prepare for the parceling out of large landed estates, which was important for the settlement campaign. The target task was to run specialized farms that would supply the entire agriculture with seed and breeding material. After the escape of S. Mikołajczyk, the communists changed the priorities of PNZ activity, which from then on were to deal with large-scale production, and above all, manage about 1,200 hectares of agricultural land. The vast majority of the area used by PNZ was located in the western and northern regions of the country. The best conditions existed in those areas for establishing a state sector in agriculture. In spite of many achievements, PNZ was liquidated because the communists wanted to get rid of the prewar staff of specialists, mostly landowners, from the enterprise. This decision was political in nature. State farms were then created to replace PNZ.
\end{abstract}

Keywords: state farms, PNZ (Państwowe Nieruchomości Ziemskie - State Agrarian Real Estate), Recovered Territories, Poland 1945-1949, agricultural policy

doi: 10.2478/sho-2021-0010

\section{INTRODUCTION}

The PNZ were created at the beginning of 1946 and were an attempt to solve the problem of management of large land estates taken over by the state. This problem occurred on a huge scale on post-German lands 
[Maringe W., Englicht W. 1959: 38]1․ There were several thousand granges with an area exceeding 100 ha, which occupied a total of 4.3 million ha (including 1.9 million ha of farmland) [Łach S. 1993: 94]. A significant part of those lands were the so-called "dead estates" - largely destroyed as a result of war activities and post-war devastation. They were usually abandoned by previous German employees. The restoration of agricultural production there required the use of methods adapted to large agricultural complexes and was associated with the need to hire specialists, which was extremely difficult in the conditions of the post-war personnel shortage. The restoration of agriculture, as well as the development and settlement of the entire area of what was then called the Recovered Territories, posed an enormous organizational and financial challenge to the state.

In the early postwar years, the policy of the authorities regarding the areas acquired in the west was not unequivocal. On the one hand, it was determined by the need to use the existing economic potential and to integrate them with the former territories, as well as by the need for rapid settlement with the Polish population. On the other hand, the communists, taking advantage of favourable circumstances, from the very beginning strived to implement the systemic transformation as quickly as possible [Makowski A. 2006: 59]. The aim of this article is an attempt to give a synthetic account of the short period of activity of an institution which played a significant role in the management of the Recovered Territories and initiated the construction of the state sector in Polish agriculture. Due to the specific nature of the post-German territories and the concentration of PNZ activities in this area, the present discussion will be limited to only these areas.

\section{ESTABLISHMENT AND ORGANIZATION OF STATE AGRARIAN REAL ESTATE}

In 1945, the post-German estates, which were not occupied by the army or other various state institutions and offices, became the property of the land offices. However, administering them exceeded the capabilities and competencies of the small staff of officials. Therefore, most of the estates

${ }^{1}$ In the so-called old lands the problems with management of estates taken over by the state were much smaller. This was due to their smaller number (except for Greater Poland and Pomerania), lesser damage due to war and post-war degradation, as well as better personnel situation - as a rule the former farm workers were retained. Estates with an area of more than 50 hectares were transferred to PNZ. 
deteriorated and became the prey of looters and local settlers. Therefore, there was a need to create a separate state institution, which would take over the administration of 1.5-2 million hectares of agricultural land and prepare the estates, therein, for parceling out or further functioning as part of the state sector of the economy [Kaliński J. 2008: 250-1].

For the future fate of the estates in question, it was crucial to determine the future agricultural system of the Recovered Territories. In the political and scientific discussions that took place at the time, the complete parceling out of large farms was not considered. Most political groups agreed that part of the agricultural areas of the post-German territories should be left in the hands of the state for public purposes, especially for specialized agricultural culture centers. However, it was much more difficult to agree on how large this portion should be. PSL advocated the parceling out of most of the resources and the creation of relatively large, economically strong individual farms while limiting the state domain. This concept differed from the one promoted by the PPR, for which the possibility of retaining a much larger area in the hands of the state was an excellent starting point for implementing the program of restructuring the agrarian structure and ownership relations in the countryside. However, the communists realized that parceling out part of the land was one of the conditions for the success of the resettlement action. Settlers, regardless of their origin, were mainly interested in the possibility of obtaining an individual farm [Machałek M. 2012: 114-123]. The lack of clarity regarding the results of the resettlement action and the limited influence of the PPR on the Ministerstwo Rolnictwa i Reform Rolnych (hereafter MRiRR; Ministry of Agriculture and Agrarian Reform) up until it came under the authority of S. Mikołajczyk, meant that decisions on the size of the state domain in the Recovered Territories evolved. However, the final decisions on this issue belonged to the PPR.

The first attempt at a systematic management of abandoned and deteriorating estates was made in autumn 1945 in the Lubuski region. At that time, Państwowy Zarząd Rolny Ziemi Lubuskiej (the State Agricultural Administration of Lubuska Land) was established, and its management was entrusted to Engineer Witold Maringe², who had extensive experi-

2 Leonard Witold Stanisław Maringe (1890-1966) - graduated from the Institute of Agronomy in Gembloux, Belgium. During the First World War he administered abandoned landed estates in Łomżyńskie. From 1918, he managed his own Lenartowo estate (376 ha) and administered several other estates. He was active in agricultural organizations, including the Union of Farmers with Higher Education in Warsaw, and was also 
ence in land administration. The essence of the idea was to concentrate forces in a single, best functioning, farm that would serve as a base for the development of neighboring granges or, at least, protect them from further devastation [Rogala W. 1972: 31; Duda H. 2006: 11-5].

The good results of this enterprise became an impulse to create a larger institution, covering the entire Recovered Territories. On 17 January 1946, Stanisław Mikołajczyk, Minister of Agriculture and Agricultural Reform, granted W. Maringe the power of attorney to organize the State Agrarian Real Estate [Rogala W. 1972: 23; AAN, Zarzad Centralnych..., sign. no 34: $3]^{3}$. This date is assumed to be the beginning of PNZ's activity, although the legal act establishing the enterprise, as well as its statute, were never published. The ambiguities surrounding the beginnings of PNZ led Radosław Gross to formulate the hypothesis that the lack of relevant legal acts was a deliberate action of S. Mikołajczyk, who wanted to maintain full control over the activities of the enterprise and the tasks carried out by it [Gross R. 2019: 433].

The Central Board, i.e. the management of the enterprise was located in Poznań. Such a location ensured better transport links with the western lands, where most of the estates were located and with a better likelihood of finding specialists in the farming traditions of Greater Poland. Perhaps the founders of the PNZ were also concerned with a certain autonomy as a result of its distance from the political center. Initially, in the field, nine districts were created, whose borders coincided with the provincial areas (except for Szczecin and Olsztyn provinces, where, due to the large area and number of estates, two district boards were created in each)

director of the Economic Office of Chambers and Agricultural Organizations and the Agricultural Industry of the Poznan and Pomeranian Voivodships. During the German occupation, he engaged in conspiratorial activity. He was director and then deputy director of the Agriculture Department of the Government Delegation for Poland. He was involved in preparing plans for the development of the so-called postulated lands in the west and north. After the liberation, he actively participated in the reconstruction of agriculture in Greater Poland as a plenipotentiary of the Sowing Operation. In the years 1946-1949, he was the chief director of PNZ. He was arrested in 1949 and after two years of investigation sentenced to life imprisonment. After his rehabilitation in 1956 he was employed as the head of the Research Workshop of Economics and Organization of Agricultural Production of the Polish Academy of Sciences. In the years 1957-1966 he became an advisor to the Minister of Agriculture. The author of many works in the field of agricultural economy [Ziemianie polscy... 1996: 115-6].

${ }^{3}$ For more on the controversy over the date of PNZ's establishment [Duda H. 2006: 20-1]. PNZ also appears in documents as Zarząd Państwowych Nieruchomości Ziemskich. For more on the controversy over the name: Maciejko K. [2015: 125-140]. 
[AAN, Zarząd Centralny..., sign. no 45: 14-7]. However, already by April of 1946, the PNZ activity had extended to include the area of the entire country by creating other six district boards (although, except for Poznan and Bydgoszcz districts, the number of estates taken over by the PNZ was small $)^{4}$.

PNZ was to carry out two basic types of tasks: permanent and temporary. The permanent task was to run specialist farms serving as centers of agricultural culture. The temporary task was to manage the estates earmarked for parceling and to run agro-based industries until they were transferred to new users. In addition, PNZ was to perform other tasks of "agricultural-administrative or agricultural-inspecting nature" commissioned by MRiRR [Duda H. 2006: 22; Machałek M. 2012: 158-9]. The draft statute also stipulated that the activities of the enterprise should be based on economic principles, yet taking into account the current needs of agriculture. The management of PNZ pointed out that in practice this meant the need to reconcile mutually exclusive tasks [AAN, Zarzad Centralny..., sign. no 60: 2-20].

\section{ECONOMIC PROBLEMS}

By February of 1946, the PNZ began to take over estates with an area of more than 100 hectares from the land offices, along with agro-based industries, buildings, equipment and other resources. Some selected farms with smaller acreages were also transferred to PNZ provided they had appropriate conditions for establishing agricultural culture centers there [Rogala W. 1972: 23; AAN, Zarzad Centralny..., sign. no 60: 65-8]. According to data, from February 1, 1946, there were more than 8,000 estates of more than 100 hectares in the PNZ area [AAN, Zarzad Centralny..., sign. no 45: 2]. By July 1946, 5610 farms had been taken over, including 4210 located on former German lands. At the end of that year, the total area of land under PNZ administration was 1.57 million hectares (including 1.271 million hectares of arable land), with the estates on former lands occupying only 330 thousand hectares [APSZ, Państwowe Nieruchomości..., sign. no 32: b.p.]. The holdings of the PNZ, however, remained fluid. The estates that had been prepared and partially developed (ploughing and partial

4 The Cracow district was liquidated in June 1947 due to too few estates [Rogala W. 1972: 52]. 
sowing) were systematically transferred for division among the settlers, while others were taken over to the stock. Due to the ongoing settlement campaign, parceling out was treated as a priority; therefore the acreage administered by PNZ was systematically decreasing.

In June 1946, the target size of the state domain was set in a circular issued by the Ministry of Agriculture and Rural Development at $10 \%$ of the total agricultural land in the western and northern lands. This land was to be used, not only for PNZ activities, but also for other public purposes. At the same time, it was assumed that most estates over 100 hectares temporarily administered by PNZ would be allocated for parceling out or for agricultural education. It was planned to allocate around 600,000 hectares of the Recovered Territories (mostly in Western Pomerania and Lower Silesia) for permanent administration of the PNZ) ${ }^{5}$. It is worth adding here that in the opinion of the Central Board of PNZ, no more than 480 thousand hectares were needed in the whole country for this purpose, i.e., for running agricultural culture centers [Rogala W. 1972: 144]. The same size of the state domain, 10\%, was repeated in the decree of 6 September 1946 on the agricultural system of the western and northern lands ${ }^{6}$. The above regulations meant that in the following months, the PNZ's main effort remained directed at preparing the seized land estates for transfer to the settlers.

After the removal of S. Mikolajczyk from the post of Minister of Agriculture and Agrarian Reform, the Polish Workers' Party (PPR) gained a voice in the matter of agricultural policy. The new leadership of the Ministry of Agriculture and Rural Development changed its attitude regarding the tasks carried out by PNZ. Agricultural culture centers, which were to be run by PNZ, were considered a secondary activity, while the large-scale agricultural production became the most important task. The plans regarding the size of the area allocated to PNZ also changed.

At a conference held in September 1947 with representatives of the Ministry of Agriculture and Rural Development and the Ministry of Recovered Territories, the possibility of increasing the state domain to about 1.8 million ha was considered. Ultimately, it was agreed that its size would be 1.65 million hectares across the country, of which 1.2 million

${ }^{5}$ Circular No. 10 of 5 June 1946 concerning the settlements on recovered territories [Dz. Urz. MRiRR 1946, nr 7, poz. 91:18]. R. Gross points out that, originally, the rate was to be lower by half (5 percent) [Gross R. 2019: 437].

${ }^{6}$ Decree of 6 September 1946 on the agricultural system and settlements on the territory of the Recovered Territory and the former Free City of Gdansk [Dz. U. 1946, nr 49, poz. 79]. 
hectares was allocated to PNZ. As it was to turn out later, this was not the final size. It was also decided to limit the area allocated for parceling and it was stipulated that only estates that were smaller in area and had a sufficient number of residential and livestock buildings could be transferred for this purpose [Dziurzyński P. 1983: 128-9; Łach S. 1993: 118]. This was a significant change. As a consequence, in the fall of 1947 another segregation of estates was carried out, as a result of which some insufficiently settled estates that had previously been transferred to individual settlers or to settler-parcelling cooperatives, returned to the PNZ [AAN, Zarzad Centralny..., sign. no 154: b.p.; AAN, Ministerstwo Ziem..., sign. no 50: 173].. In the following year, all estates that were not yet occupied were incorporated into the PNZ, and even some of those with an area of less than 100 hectares as well as post-regulation land bordering on PNZ agricultural complexes, were included in the PNZ.

These activities coincided with a change in government policy towards the Recovered Territories. The process of restructuring and integration of these areas with the so-called "old lands" was then considered complete as reflected, among other things, in the liquidation of the Ministry of Recovered Lands and their role as the country's food supply base (especially the Olsztyn, Szczecin, Koszalin and Zielona Góra provinces) [Makowski A. 2006: 68]. In the following months, the expansion of the state sector in agriculture became a priority for the authorities, alongside collectivization. This was mainly due to ideological reasons, but the lower-than-expected effects of the settlement action also played an important role in the decisions taken at that time.

Changing political ideas about the size of the state domain were the main, but not the only, obstacles to the rational planning and efficient management of PNZ. The enterprise included estates in the worst conditions because the better ones had been previously occupied by offices and institutions or the military. Most of the acquired property was neglected (some fields had not been sown as far as since the fall of 1944), damaged, looted, and in the case of property acquired from the Red Army, completely exploited. There was a lack of everything needed to start production, such as grain for sowing, livestock and draught animals, agricultural equipment (even the existing machines and equipment could not be fully operated due to a lack of fuel, spare parts and qualified tractor drivers and mechanics) [AAN, Zarzad Centralny..., sign. no 84: 2-7]. The PNZ leadership estimated that only a few percent of the estates taken over in 1946 were sufficiently managed [AAN, Zarząd Centralny..., sign. no 1642: b.p]. 
By the turn of 1946 and 1947, the management of the enterprise tried to defend itself against taking over successive fallow and ruined land estates, arguing that it lacked adequate forces and resources [Gross R. 2019: 439]. Over time, the problem worsened as more ruined estates (including those handed over by the Red Army) and even single farms were transferred to the PNZ. This caused the dispersion of land owned by the PNZ and raised the cost of operations.

As mentioned earlier, in the first year of PNZ operations, the priority was matters related to parceling. The management of the enterprise, understanding its importance for the course of the settlement action, however, did not neglect preparations for the implementation of the target task, which was to run agricultural culture centers. These were to be model farms specializing in the cultivation of selected plant species and pedigree animal husbandry for the needs of the entire agriculture sector [ $A A N$, Zarzad Centralny..., sign. no 52: b.p.].

In June 1946, in consultation with the land offices in all districts, facilities with the best conditions for specialized farms were selected [AAN, Zarzad Centralny..., sign. no 45: 5]. They, immediately, began to be put into operation, investing considerable effort and resources. However, contrary to earlier arrangements, many already developed centers were later taken over by settlement institutions and transferred for parceling [Machałek M. 2012: 173-4]. This often happened without any agreements with the PNZ. The military authorities also acted in a similar way, seizing and parcelling out prosperous estates among military settlers [AAN, Zarząd Centralny..., sign. no 241: b.p.].

The conflicts of interest also concerned the equipment and resources in the estates transferred for parceling. The settlement authorities and the settlers expected to leave as much equipment and livestock as possible. However, the PNZ management tried to withdraw as many agricultural machinery and equipment as possible, arguing that it would not be fully utilized on small farms. The issue of livestock given to the settlers was even worse. It was also not unusual for settlers to sell their animals and leave the allocated land, taking some of their belongings with them [Machałek M. 2012: 174].

It was obvious that the outlays incurred in preparing the estates for parcelization could not be amortized, but the chaos that often accompanied it caused organizational paralysis and thwarted economic plans and whatever sense previous efforts made [Machałek M. 2012: 172-3]. Under such conditions, achieving the expected economic results was not possible. 


\section{STAFFING ISSUES}

Staffing issues were crucial to the functioning of PNZ. People devastated by war and occupation were sent to work on state farms in the Recovered Territories - forced labourers, displaced persons from the lands lost to the East and from the overcrowded and poorest villages of former territories. Common problems included malnutrition and numerous diseases, such as tuberculosis, and even such mundane issues as lack of appropriate clothing. Director W. Maringe estimated that due to the poor physical condition of the employees, labor productivity decreased by $30 \%$ compared to the pre-war period) [AAN, Zarzad Centralny..., sign. no 84: 2-7]. Many of the employees had no experience working in agriculture. Above all, there were too few of them. Quantitative and qualitative deficits affected every group of workers, and the scale of the problem was so large that it impeded the normal functioning of the enterprise.

Immediately after the commencement of activities, the Central Board of PNZ estimated that in order to efficiently launch minimal agricultural production on farms located on new lands, approx. 70 thousand workers were needed [Duda H. 2006: 134; AAN, Zarząd Centralny..., sign. no 312: 14]. Only the Eastern Mazurian and Opole districts had adequate numbers of workers at their disposal at that time, while two districts (Wrocław and Legnica) had a slight surplus. The greatest shortages of staff, however, were experienced by the PNZ district boards in Gdańsk, Olsztyn, Koszalin and the Lubusz area. In 1948, there was still a shortage of at least 24,000 families [AAN, Zarzad Centralny..., sign. no 84: 2-7]. The problem of staff shortages grew as the PNZs' holdings increased.

German workers played an important role in the Recovered Territories, especially at the initial period. At the time PNZ was established, the resettlement of the German population was already a foregone conclusion, but for months that followed they still made up the vast majority of employees on many farms. According to various estimates, in the spring of 1946 there were around 55,000 employees, while the number of Polish employees was estimated at less than 10,000 in the first few months of the PNZ's activities [Duda H. 2006: 134]. Over time, the proportions between the number of Poles and Germans employees changed, but more slowly than expected. As late as January 1947, some workplaces recorded an almost complete lack of Polish workers. The expulsion of Germans aggravated the already difficult personnel situation, so the management of PNZ tried to keep them on, if only for the harvest season [Machałek M. 2012: 
185]. However, the situation became complicated. The presence of German workers, although justified economically, was perceived poorly by potential settlers. Poles were more willing to settle in estates where German workers were no longer present. After the expulsions ended, a significant number of Germans still remained, most of them in the area of the District Administration in Koszalin, where around six thousand German workers worked [Machałek M. 2012: 185].

Getting people that were willing to work on state property, especially in the Recovered Territories, was difficult. Settlers were mainly interested in individual farms, preferably the so-called "warm farms" or those suitable for immediate settlement [Gross R. 2019: 441]. The low social prestige that the job of an agricultural worker had before the war (except in Wielkopolska and Pomerania) was also not encouraging. Young people, in particular, chose the much more attractive opportunity to work in industries, often associated with social advancement.

Another factor that made it difficult for PNZ estates to attract workers was poor living conditions. The housing that farms provided for employees was often in a terrible state. However, the most important problem was low wages - $40 \%$ lower than in other branches of the socialized economy [Dzun W. 1990: 117] and lower than the wages of farm workers before the war [Gross R. 2019: 464]. They consisted of two parts - cash (initially small, constituting less than $5 \%$ of the total remuneration) and inkind (deputation in kind). Although this solution was advantageous for employees in the supply situation of that time. PNZ had great difficulties with both the payment of salaries in cash and benefits in kind. Irregular payments not only caused complaints and strikes, but sometimes condemned workers to starvation [Gross R. 2019: 451-64]. This situation was one of the causes of the scourge of theft ${ }^{7}$.

Unwillingness by some to work on state property, especially in the Recovered Territories, also applied to white-collar workers, administrators, managers, bookkeepers, and the like. Therefore, anyone who wanted to work was employed, including those without an agricultural or economic education. Courses and training organized by PNZ could bear fruit only in the long term. With respect to day-to-day operations, the lack

7 Thefts committed by PNZ's employees also resulted from a general loosening of moral norms, a lack of authority, and the belief that state property was "nobody's property". It is worth noting that such thefts were also committed on a large scale by employees of state farms (PGR) and those employed in other sectors of the economy. 
of professional training and poor selection of personnel translated into management errors, low production results and economic negligence. Mismanagement, theft, embezzlement and other abuses resulting from lack of supervision or improper accounting were also commonplace. The management of PNZ tried to combat these phenomena, but were publicly denounced, and the press amplified reports on court judgments and disciplinary dismissals [AAN, Zarząd Centralny ..., sign. 2394: b.p.].

The consequence of these problems was a huge turnover of both bluecollar and white-collar workers. Job abandonment often occurred overnight. Changes in the positions of administration and governments were particularly acute. Situations when several governments and administrators changed within one farm or team during the year were not exceptions. Huge staff turnover was a problem not only for PNZ, but also later for state farms.

Against the background of the company's personnel weakness, the group of people employed in the Central Board and in most district boards in the Recovered Territories stood out. Its core consisted of agricultural specialists well prepared to manage large estates. These were landowners who had lost their own properties as a result of the land reform, as well as pre-war administrators of land estates. Their employment was the responsibility of Director W. Maringe, to whom S. Mikolajczyk gave a free hand in personnel matters. This group can be considered as one of the greatest assets of the enterprise. The knowledge and professional experience of these people were crucial to the interests of the enterprise. For the communists, however, they were class aliens and politically suspicious, especially since the members of the leadership were linked 4 not only by professional matters, but also by numerous informal interpersonal ties.

The selection of personnel was a concern to PPR from the beginning. Accusations that PNZ became a hotbed of reaction, and that the "landowners" ruling the enterprise were acting to its detriment, were formulated even while S. Mikołajczyk was still the Minister. Indeed, the management of PNZ approached the concept of reconstruction of the agricultural system with reserve, but the accusations were based solely on political considerations $^{8}$. Although former landowners held the most prominent managerial positions, surviving source materials show that in 1947, they accounted for approximately $10 \%$ of the Central Board's staff. With regard to the management itself, the ratio was higher -27 percent of the di-

\footnotetext{
${ }^{8}$ For more on this topic, see Osinski T. [2012]; Duda H. [2006].
} 
rectors in the Central Board and 20 percent of the directors of the district boards were of landowner origin. Outside the Central Board, almost all persons with a landowner background were employed in the Recovered Territories. The surviving personal materials are not complete, so it can be assumed that the actual figures may have been somewhat higher (especially since some people may have deliberately concealed their origin) [Osiński T. 2012: 231; Gross R. 2019:451].

For the former landowners, the opportunity to work in the PNZ was an opportunity to find a livelihood in line with their qualifications. The main motive was, therefore, purely economic, but, as Eugeniusz Kłoczowski writes in his memoirs, many were also motivated by the conviction that it was necessary to work for the state [Kłoczowski E. 1996: 20]. Actions to the detriment of the enterprise would, therefore, have been against their own interests. Another issue is that in the difficult conditions in which PNZ operated, it was indeed difficult to achieve the expected results and many irregularities occurred, such as mismanagement or lack of supervision over employees. These problems were the result of a lack of strength and resources rather than deliberate action.

However, a massive campaign against the PNZ management began only after the escape of S. Mikołajczyk. In June 1947, the verification of PNZ staff was announced by Minister Jan Dąb-Kocioł, speaking at the First Assembly of Agricultural Workers and Labourers in Szczecin [AAN, Zarzad Centralny..., sign. 75: b.p.]. In the Central Board, and later in the district boards, personnel departments were established and staffed by PPR representatives. Huge personnel purges began, targeting people with "improper" social backgrounds and "improper" political views. Most often the basis for dismissals or arrests were real or fabricated accusations of sabotage or economic abuse.

In April 1948 the entire management of the District Board of PNZ in Koszalin was arrested with its director Władysław Czarnecki at the head. The trial took place before the Military District Court in Szczecin and had the character of a show. The penalties imposed were extremely harsh. Czarnecki was sentenced to death, loss of public rights and forfeiture of property, while others received sentences ranging from 2 to 15 years imprisonment [Ptaszyński R. 2008: 35; Machałek M. 2012: 193; AIPN SZ]9. Similar situations occurred in other district boards [Gross R. 2018; Duda

\footnotetext{
${ }^{9}$ By a decision of the Supreme Military Court, the sentence for W. Czarnecki was commuted to 15 years. For more on the trial, Ptaszynski R.[ 2008: 35]; Romanow Z. [2017].
} 
H. 2006: 61-70]. Personnel purges, criminal cases, and prolonged propaganda campaigns were aimed at intimidating the remaining employees and, above all, discrediting the PNZ management in the eyes of the public. In this atmosphere, the arrests and resignations of many high-level professionals from PNZ translated into a deterioration of economic performance in the final months of the company's operations [Gross R. 2019: 454].

The final stage of the crackdown on the PNZ management was the arrest of its creator and general director, W. Maringe, along with other employees of the former Central Board. This happened after the process of PNZ liquidation was completed (the decision on liquidation was taken in February 1949) and State Agricultural Farms were created on their basis ${ }^{10}$. Until June 1949, W. Maringe performed the duties of liquidator of the enterprise, while his arrest took place in August 1949, and the trial took place only after two years of preparations.

The process of political purges begun as early as in 1947 did not end with the liquidation of PNZ, but continued, as the PGR (State Agricultural Farms), due to a lack of suitable staff, were forced to take over some of the PNZ staff [Machałek M. 2011: 134]. These people were exchanged in subsequent years for people from the so-called social promotion.

\section{CONCLUSIONS}

PNZ was liquidated after less than three years of existence, so it is extremely difficult to assess the effects of its activities. Most plans and investments were discontinued and no reliable balance sheet was available. PNZ operated in extremely difficult conditions, mainly in the Recovered Territories. Despite numerous limitations, in a relatively short period of time they settled and managed thousands of properties with an area of more than 100 hectares, preventing their further devastation. Thousands of hectares were prepared for settlement and parceling by plowing, planting, building repairs and partially rebuilding livestock ${ }^{11}$. Workplaces and living quarters created in individual estates were also of great im-

${ }^{10}$ W. Maringe, Władysław Englicht and Kazimierz Papara received life imprisonment sentences. Other members of the Central Board leadership received sentences of 10-15 years in prison. Feliks Sommer and Tadeusz Krzyżanowski died in prison. In 1956, they were all rehabilitated. [Osinski T. 2012: 24-258; Slaski L. 1992].

11 AAN, Ministerstwo..., sign. no 50: 176. 
portance. Thus, they played an important role in the process of settling the Recovered Territories. PNZ also opened agricultural culture centers, which began to provide farmers with seed and breeding material. These are undoubtable successes that were achieved in spite of the unfavorable economic and political conditions and with a constant deficit and turnover of workers [Gross R. 2019: 445].

Ingeneral, theintensivesettlementcampaignontheRecoveredTerritories did not bring the expected results. This meant that regardless of political concepts, there was no need to parcel out all the large land estates on the Recovered Territories ${ }^{12}$. Their management by a state institution remained the only alternative in the political conditions of the time. PNZ had the potential to cope with this task (although it probably would have been with great difficulty). However, as Hilary Minc said, already in 1948, from the beginning they were burdened with the "curse of Mikołajczyk's rule" in MRiRR [Minc H. 1998: 266]. In the new reality, there was no place for an institution as autonomous as PNZ. The liquidation of PNZ was inevitable because it resulted from a change in economic policy and was intended to facilitate "the development of a rural socialist economy" [Kozlowski K. 2007: 355]. The communists also decided to erase all traces of the existence and achievements of the enterprise, so strongly associated with the "landowners". To a large extent, they succeeded in this - in the popular consciousness, the state agricultural sector is associated mainly with PGR.

\section{BIBLIOGRAPHY}

\section{Archival material}

AAN (Archiwum Akt Nowych), Zarząd Centralny Państwowych Nieruchomości Ziemskich, sygn. 34, 45, 52, 60, 75, 84, 154, 241, 312, 1642, 2394.

AAN (Archiwum Akt Nowych), Ministerstwo Ziem Odzyskanych, sygn. 50.

APSZ (Archiwum Państwowe w Szczecinie), Państwowe Nieruchomości Ziemskie Zarząd

Okregowy w Szczecinie, sygn. 32.

AIPN SZ (Archiwum Instytutu Pamięci Narodowej Oddział w Szczecinie), sygn. 61/222 t. 7.

\section{Legal Acts}

Dz. Urz. MRiRR 1946, nr 7, poz. 9, Okólnik Nr 10 z 5 VI 1946 r. w sprawie osadnictwa na ziemiach odzyskanych.

12 It is also worth noting that after the liquidation of the state farms (PGR) at the beginning of the 1990s - the largest number of large farms is found in the Western Pomeranian and Warmian-Masurian Voivodeships [Wawrzyniak B. M., 2004]. 
Dz. U. 1946, nr 49, poz. 79, Dekret z 6 IX 1946 r. o ustroju rolnym i osadnictwie na obszarze Ziem Odzyskanych i byłego Wolnego Miasta Gdańska.

\section{Printed sources and memoirs}

Minc H. (1998), Bieżące zadania Partii w zakresie polityki gospodarczej i społecznej na wsi [in:] Sprawozdania stenograficzne z posiedzenia Komitetu Centralnego Polskiej Partii Robotniczej 31 sierpnia - 3 września 1948 r., Kochański A. (ed.), Naczelna Dyrekcje Archiwów Państwowych, Pułtusk-Warszawa.

Kłoczowski E. (1996), Moja praca w Państwowych Nieruchomościach Ziemskich w Poznaniu (1946-1949), Kaczmarek Z. (ed.), Wydawnictwo Akademii Rolniczej w Poznaniu, Poznań.

Slaski L. (1992), Lata wykreślone z życia. Proces polityczny i więzienia PRL, Oficyna Literacka, Kraków.

\section{Literature}

Duda H. (2006), Państwowe Nieruchomości Ziemskie w Opolu (1946-1949). Zarys monograficzny, Stowarzyszenie Instytut Śląski [etc.], Opole.

Dziurzyński P. (1983): Osadnictwo rolne na Ziemiach Odzyskanych, Ludowa Spółdzielnia Wydawnicza.

Dzun W. (1990): Państwowe gospodarstwa rolne w rolnictwie polskim 1944-1990, Polska Akademia Nauk, Instytut Rozwoju Wsi i Rolnictwa, 117

Gross R. (2018), Inwigilacja i proces kierownictwa Zarządu Okręgowego Państwo wych Nieruchomości Ziemskich w Olsztynie, Dzieje Najnowsze, 50(2), 215-246.

Gross R. (2019), Przemiany gospodarcze na Warmii i Mazurach w latach 1945-1956, Wy dawnictwo Uniwersytetu Warmińsko-Mazurskiego, Olsztyn.

Kaliński J. (2008), Historia gospodarcza XIX i XX w., Polskie Wydawnictwo Ekonomiczne, Warszawa.

Kozłowski K. (2007), Od Państwowych Nieruchomości Ziemskich do likwidacji Państwowych Gospodarstw Rolnych na Pomorzu Zachodnim [in:] Szaflik J. R. (ed.), Dzieje partii i stronnictw chłopskich w Europie, t. 2: W podzielonej Europie, Akademia Humanistyczna im. Aleksandra Gieysztora, Oficyna Wydawnicza Aspra-JR, Kongres Historyków Wsi i Ruchu Ludowego, Pułtusk.

Łach S. (1993), Przeksztatcenia ustrojowo-gospodarcze w rolnictwie ziem zachodnich i pótnocnych w latach 1945-1949 (studium historyczne), Wydawnictwo Wyższej Szkoły Pedagogicznej w Słupsku, Słupsk.

Machałek M. (2012), Przemiany wsi zachodniopomorskiej, Wydawnictwo Muzeum Narodowego w Szczecinie, Szczecin.

Machałek M. (2011), Społeczne warunki funkcjonowania państwowych gospodarstw rolnych na Pomorzu Zachodnim w latach 50. I 60. XX w. Wybrane problemy [in:] Jankowiak S., Skotarczak D., Skórzyńska I. (eds.), Społeczeństwo PRL. Historia. Kultura. Pamięć, t. 1: Historia, Instytut Historii UAM, Poznań.

Maciejko K. (2015), Zarząd Państwowych Nieruchomości Ziemskich czy Państwowe Nieruchomości Ziemskiej - problem nazwy zespołu na tle dziejów jego twórcy, Archeion, CXVVI, 125-140.

Makowski A. (2006), Ziemie Zachodnie i Pótnocne w polityce gospodarczej Polski w latach 19451960 [in:] Sakson A. (ed.), Ziemie Odzyskane/Ziemie Zachodnie i Pótnocne 1945-2005. 60 lat w granicach państwa polskiego, Instytut Zachodni, Poznań.

Maringe W., Englicht W. (1959), Państwowe Gospodarstwa Rolne (zarys rozwoju w kolejnych okresach), Zagadnienia Ekonomiki Rolnej, 34(4), 36-56.

Osiński T. (2012), „Klika obszarnicza”. Ziemianie w polityce personalnej Państwowych Nieruchomości Ziemskich (1946-1949), Pamięć i Sprawiedliwość, 2(20), 229-260. 
Ptaszyński R. (2008), Sędziowie Wojskowego Sądu Rejonowego w Szczecinie i ich wyroki. Studia i materiaty, Instytut Pamięci Narodowej, Szczecin.

Romanow Z. (2017), Proces Zarządu Okręgowego Państwowych Nieruchomości Ziemskich w 1948 roku, Zapiski Historyczne, 82(3): 85-109.

Rogala W., (1972), Działalność Państwowych Nieruchomości Ziemskich (1946-1949), Rocznik Muzeum Rolnictwa w Szreniawie, t. V.

Wawrzyniak B.M. (2004), Kierunki ewolucji struktury agrarnej Polski w świetle spisów rolnych 1996 i 2002 r., Acta Scientiarum Polonorum. Oeconomia, 3, 124-135.

Ziemianie polscy XX wieku (1996), Leskiewiczowa J. (ed.), Słownik biograficny, cz. 3., DiG, Warszawa.

Małgorzata Machałek, dr hab., prof. US, University of Szczecin. Scientific interests include the recent history of Poland, with particular emphasis on the history of villages and agriculture after World War II, as well as regional history and historical education. 